\title{
STUDIES ON PHYSICAL PROPERTIES OF BUKIT KAMANGS' LIMESTONE AS MINERAL SOURCE FOR LAYING HENS
}

\author{
Khalil ${ }^{1}$, B. Primasari ${ }^{2}$ and S. Anwar ${ }^{1}$ \\ ${ }^{1}$ Faculty of Animal Science, Andalas University, \\ Kampus Limau Manis, Padang, West Sumatera - Indonesia \\ ${ }^{2}$ Faculty of Engineering, Andalas University, \\ Kampus Limau Manis, West Sumatera - Indonesia \\ Corresponding E-mail: khalil@faterna.unand.ac.id
}

Received April 22, 2011; Accepted July 22, 2011

\begin{abstract}
Samples of limestone composites were measured for hardness in 5 difference colors: black, dark blue, blue, light blue and white. Limestone was then ground and particle sizes of meal were measured. The meal were mixed with other locally available materials to produce 5 difference mineral formulas: P1: $100 \%$ limestone meal, P2: $50 \%$ limestone meal $+50 \%$ fresh water oyster shell meal, P3: $35 \%$ limestone meal $+30 \%$ fresh water oyster shell meal $+35 \%$ bone meal, P4: $35 \%$ limestone meal $+30 \%$ fresh water oyster shell meal $+34.2 \%$ bone meal $+0.5 \%$ salt $+0.3 \%$ micro minerals and P5: $100 \%$ fresh water oyster shell meal. The formulas were stored for 12 weeks. Samples were taken weekly for analyzing of moisture content and physical properties. By a feeding trial the five mineral formulas were mixed in the level of $6 \%$ into basal diet and fed to 150 laying hens for 24 weeks. Parameters measured included body weight, feed intake, egg production and FCR. Results showed that the composites of Bukit Kamangs' limestone had difference hardness. The strongest was found by the black composite of 23.4 HRc-C or 245.0 BHN. The meal products contained large particles $(>0.42 \mathrm{~mm})$ of $17.8 \%$. Moisture content of mineral formulas increased during storage, but their physical properties were no significant changes. The highest moisture increase was found by the product of $100 \%$ limestone, but it could be reduced by mixing with oyster shell meal and bone meal. The best laying performances $(\mathrm{P}<0.05)$ were found by the hens fed with diet supplemented with mineral formula containing limestone, fresh water oyster shell and fortified with micro minerals.
\end{abstract}

Keywords: mineral feed, limestone, physical properties, laying nutrition

\section{INTRODUCTION}

Limestone of Bukit Kamang is a product of milling industry in meal form produced by crushing and grinding of natural limestone deposit located at Bukit Ujung, Kamang Mudik sub district, Agam district, and West Sumatra province. The product is normally used or sold as fertilizer for soil liming. It could also be utilized for animal feed, while Bukit Kamangs' limestone is rich on several essential minerals of $\mathrm{Ca}$ (38-40 $\%)$, Se (388 ppm), Fe (295 ppm) and Mn of 205 ppm (Khalil and Anwar, 2007)

Results of previous studies showed that the use of Bukit Kamangs' limestone as main source of $\mathrm{Ca}$ in the diet of layer chickens gave better effect on laying performances than that of fresh water oyster shell meal, which was widely used by farmers in West Sumatra (Khalil and Anwar, 2009). Moreover, when limestone of Bukit
Kamang is mixed with fresh water oyster shell meal and bone meal and enriched with limited essential micro minerals, such complete mineral formula composed of mainly local materials improved egg production and feed utilization efficiency (Khalil, 2010).

Besides of high minerals, the superior nutritive values of Bukit Kamangs' limestone are presumably due to its particular physical characteristics which are composed of particles in different hardness and sizes. Limestone of Bukit Kamang in original slab form composed of various deposits which appear from its diversified colors and structures. Deposit components show colors from clear white, blue, dark blue till black. Components with different colors have different mineral composition. Dark components with dark blue and black colors, for examples, contained high Fe (Khalil and Anwar, 2007). Such component particles were dominantly found in 

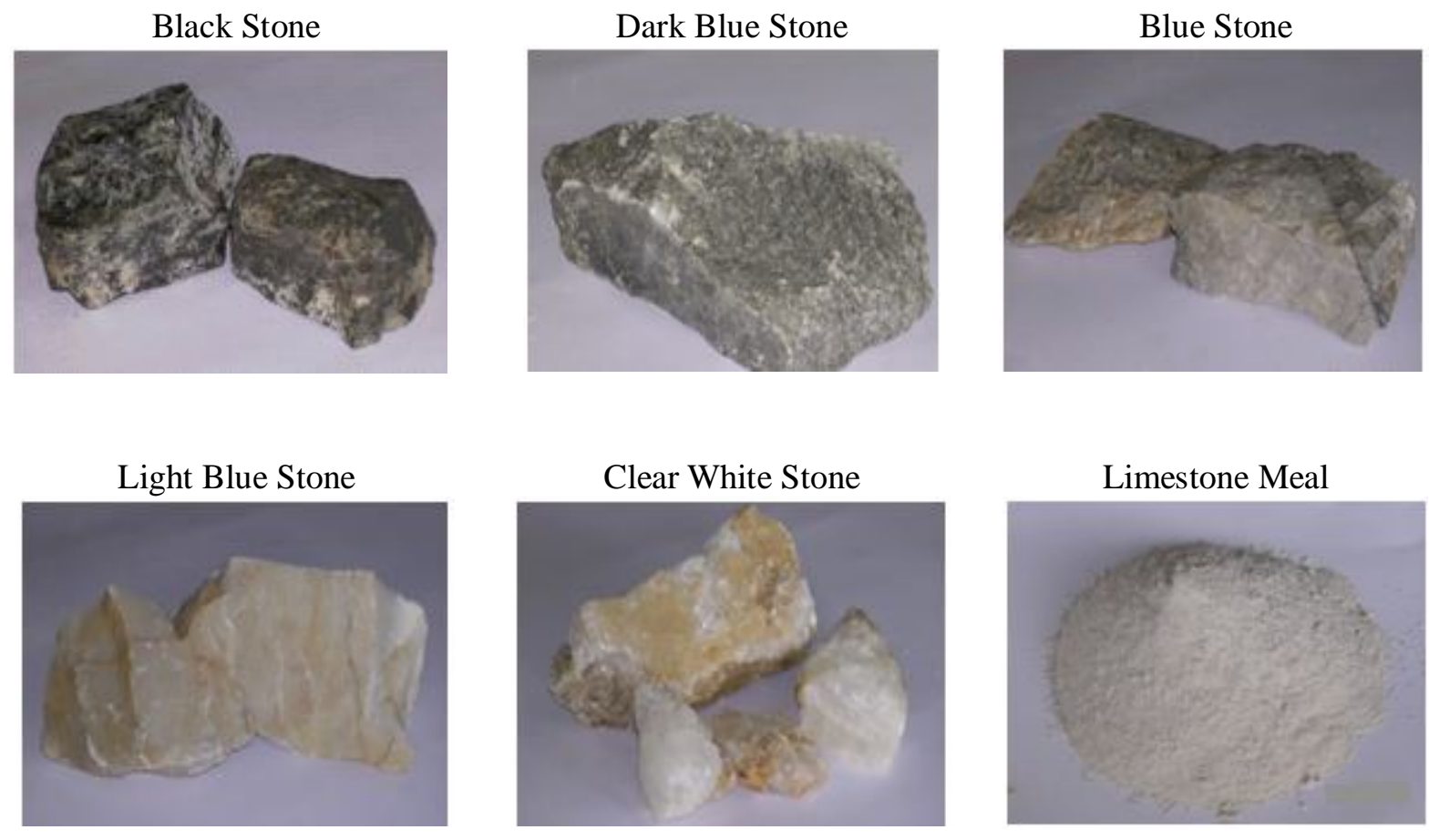

Figure 1. Composites of Bukit Kamangs' Limestone in Different Colors and Limestone in Meal Form

larger size in meal product. This component seemed to have higher degree of hardness than the other colors, so that they were more resistant by milling process. According to Farmer et al. (1986), limestone meal with larger particle size would stay in longer period in the acidic environment of the gizzard which leads to provide more available ionic calcium $\left(\mathrm{Ca}^{2+}\right)$ in the small intestine during the night-time for eggshell calcification. Moreover, the larger particle have a function as grit, which help digesting process of feed in the gizzard, so that it gave positive effect on nutrient metabolism for poultry (Scholtyssek,1987) .

Limestone of Bukit Kamang contained very low of moisture of about $1.01 \%$ (Khalil and Anwar, 2007). Because of its very low moisture content which was coupled higher portion of fine particles of the product, its moisture content tend to increase during storage especially in tropical humid areas. Such hygroscopic property leads to undesirable changes of physical textures. The meal tends to form bulk in hard agglomeration which might reduce product quality and mixing efficiency by production of ration. Such hygroscopic property might be alleviated by mixing with non hygroscopic locally available materials.

The present research was aimed to study the physical properties of Bukit Kamangs' limestone in meal form in relation their superior nutritive values as mineral source for laying hens and the storage stability of the product in formula form by mixing with other locally available mineral feedstuffs.

\section{MATERIALS AND METHODS}

\section{Samples of Limestone}

Limestone in large slabs and meal forms used in this study were obtained from a limestone milling company of CV. Bukit Raya, located in Durian village, Kamang Mudik, Kamang Magek sub district, Agam district, West Sumatra.

For measuring hardness degree, samples of limestone in large slabs were taken at milling site from stone stacks as ready stocks for milling. The slab samples were selected in 5 different colors: black, dark blue, blue, light blue and clear white (Figure 1). Each color consisted of 5 slabs, so that there were 25 slabs in total. Samples of limestone in meal form were used for determination of particle sizes and storage ability and collected from the mill product which was originated from the grinding of the same stocks from which the large slabs for determination of hardness degree were taken. 


\section{Hardness Test}

Hardness degree of slabs was determined by using Rockwell machine with indenter of diamond cone under scale of C (150 kg) (Tabor, 2000). Surface of stone were previously scoured by using sand papers prior to test. Hardness degree was expressed as Brinell hardness number (BHN), where values of $\mathrm{C}$ (HRc-C) scale of Rockwell were converted to BHN through interpolation by using standard data on hardness conversion tables. BHN were expressed as force of $\mathrm{F}$ divided with indentation surface areas with following formula:

$$
\mathrm{BHN}=\frac{\mathrm{F}}{(\pi \mathrm{D} / 2)\left(\mathrm{D}-\sqrt{\mathrm{D}^{2}}-\mathrm{d}^{2}\right)}
$$

Where:

$$
\begin{aligned}
& \mathrm{F}=\text { applied force }(\mathrm{kg}) \\
& \mathrm{D}=\text { indenter diameter }(\mathrm{mm}) \\
& \mathrm{d}=\text { indentation diameter }(\mathrm{mm})
\end{aligned}
$$

Hardness test were carried out for 4 colors: blacks, dark blues, blues and light blues, while slabs with clear white color were very fragile and could not be measured with the available instrument. Five slabs were measured for each color as replicates, so that the total numbers of measurement were 20 .

\section{Particle Size Measurement}

Distribution of particle size of limestone in meal form was determined by sieve analysis. About $300 \mathrm{~g}$ samples were at first dried in oven for 24 hours. The dried samples were then washed by using filter paper No. 200 till the color of filtrate was clear. Sample was dried in the oven for 24 hours. The dried samples were then sieved for 25 minutes by using a set of sieves of number of $4,10,20,40,60,100$ and 200. The detained parts in each sieve were weighed and the percentage of each particle size was then calculated. Percentage of each particle size was weight of detained part divided with total weight of dried sample x $100 \%$. Cumulative percentage of samples detained in sieve no. $\mathrm{n}$ was the sum of sample percentage detained till sieves to-n.

\section{Storage of Materials}

In order to define the changes of moisture content and physical properties, Bukit Kamangs' limestone was stored in both original form and formulas by mixing it with other locally available mineral feedstuffs. Fresh water oyster shell meals were used as control. As Ca source in layer diet, Bukit Kamangs' limestone could be used in single or in mixture forms with fresh water oyster shell (Khalil and Anwar, 2009). If the limestone was mixed with bone meal, it could be used as $\mathrm{Ca}$ and $P$ sources, while enrichment with micro minerals of $\mathrm{Cu}, \mathrm{Zn}$ and I were produced complete mineral formula (Khalil, 2010). There were five mineral formula products as experimental treatments as follows:

Mineral formula 1 (P1) : 100\% Bukit Kamang limestone's

Mineral formula 2 (P2) : 50\% Bukit Kamangs' limestone $+50 \%$ fresh water oyster shell meal,

Mineral formula 3 (P3) : 35\% Bukit Kamangs' limestone $+30 \%$ fresh water oyster shell meal + $35 \%$ bone meal,

Mineral formula 4 (P4) : 35\% Bukit Kamangs' limestone $+30 \%$ fresh water oyster shell meal + $34.2 \%$ bone meal $+0.5 \%$ salt $+0.3 \%$ micro minerals of $\mathrm{Cu}, \mathrm{Zn}$ and $\mathrm{I}$.

Mineral formula 5 (P5) : 100\% fresh water oyster shell meal.

The products were packed in closed dark plastic wraps of $1 \mathrm{~kg}$ each. There were 39 packs for each formula, so that there were 195 packs in total for 5 treatments. The products were then stored for 12 weeks in the Laboratory of Feed Science and Technology of Andalas University. The samples were observed weekly by taking 3 packs for each formula as replications for determination of moisture content and physical properties.

Physical properties measured included angle of response, bulk density and compacted bulk density, which were relatively sensitive to moisture changes (Ruttloff, 1981). Angle of responses is angle formed by stacks of poured feed with horizontal surfaces and expressed as degree $\left({ }^{\circ}\right)$. The angle of response indicates the degree of freedom of particles to move in the stack and flow ability of feed. By increasing of moisture content, the feed tend to form agglomeration which leads to increase its angle of response.

Bulk density is ratio of weight of sample with the volume of space filled by the sample, while compacted bulk density is ratio of weight of sample with the volume of sample filled by the sample after being compacted. The physical properties were determined according method applied by Khalil (1999a) and Khalil (1999b).

\section{Feeding Trial}

A feeding trial was conducted at the Poultry Farm of Faculty of Animal Husbandry, Andalas 
Table 1. Composition of Experimental Diets

\begin{tabular}{lccccc}
\hline \multirow{2}{*}{ Feed Components: (\%) } & \multicolumn{5}{c}{ Experimental Diets with Mineral Formula Sources } \\
\cline { 2 - 6 } Concentrate feed & P1 & P2 & P3 & P4 & P5 \\
Corn & 29.9 & 29.9 & 29.9 & 29.9 & 29.9 \\
Rice bran & 39.9 & 39.9 & 41.9 & 41.9 & 39.9 \\
Bone ash & 21.9 & 21.9 & 21.9 & 21.9 & 21.9 \\
Mineral formula 1 & 2.0 & 2.0 & - & - & 2.0 \\
Mineral formula 2 & 6.0 & - & - & - & - \\
Mineral formula 3 & - & 6.0 & - & - & - \\
Mineral formula 3 & - & - & - & - & - \\
Mineral formula 4 & - & - & 6.0 & - & - \\
Mineral formula 5 & - & - & - & 6.0 & - \\
Grit & - & - & - & - & 6.0 \\
& 0.3 & 0.3 & 0.3 & 0.3 & 0.3 \\
Calculated nutrients and energy compositions: & 100.0 & 100.0 & 100.0 & 100.0 & 100.0 \\
Crude protein, \% & 17.7 & 17.7 & 17.8 & 17.9 & 17.7 \\
Crude fiber, \% & 5.3 & 5.3 & 5.0 & 5.0 & 5.3 \\
Ca, \% & 3.7 & 3.7 & 3.8 & 3.8 & 3.6 \\
P total, \% & 0.5 & 0.5 & 0.5 & 0.5 & 0.5 \\
ME, kcal/kg & 2706 & 2707 & 2727 & 2726 & 2706 \\
\hline
\end{tabular}

University, located at Limau Manis, Padang. Each mineral formula was mixed with basal diet in the level of $6 \%$. The basal diets were prepared by using three main component of commercial layer concentrate, corn and rice bran in the level of 30, 40 and $22 \%$, respectively, which were in compliance with mineral level practiced by farmers in West Sumatra (Khalid and Anwar; 2009 and Khalil, 2010). Table 1 shows the formula of the experimental diets and their nutrient and energy contents. The nutrient and energy compositions which were calculated based on chemical analysis of feed components were justified to the standard requirements of laying hens during production period recommended by NRC (1994) and Scholtyssek (1987).

The experimental diets were offered for 24 weeks to 150 laying hens of Isa Brown strain, aged 4.5-5.0 months, started by about $20 \%$ of hen-day egg production. The hens were divided into three groups, each group of 50 birds, based on body weight: light (1200-1399 g/bird), medium (1400-1599 g/bird) and heavy (1600$1769 \mathrm{~g} / \mathrm{bird})$. ). Each group which composed of 50 birds, was then subdivided into 5 subgroups in accordance with the number of treatments, so that each experimental unit consisted of 10 birds and each treatment consisted of 30 birds with three different body weights. They were randomly placed in individual battery cages. Each cage was equipped with feed and drinking water troughs. Parameters measured included: body weight, feed intake, feed conversion ratio (FCR), hen-day egg production, number and weight of egg production.

\section{Statistical Analysis}

All data were subjected to statistical analysis using variance analysis. Data of hardness test and storage ability were analyzed in a completely random design. Data of hardness test consisted of 4 different color of stone composites as treatments and 5 slabs for each colors as replicates, while data of moisture content and physical properties from storage experiment consisted of 5 mineral formulas as treatments and 3 replications Data of feeding trial were analyzed in a completely block design with 5 treatments of diets and 3 blocks of body weight as replicates. Duncan's Multiple Range (DMRT) was applied to separate means. Differences were considered significant at $\mathrm{P}<0.05$ (Steel and Torrie, 1981). 
Table 2. Results of Hardness Test of Composites of Bukit Kamangs' Limestone in Different Colors

\begin{tabular}{lcc}
\hline \multirow{2}{*}{ Colors of Components } & \multicolumn{2}{c}{ Results of Hardness Test } \\
\cline { 2 - 3 } & HRc-C & BHN \\
\hline Black & $23.4(14.0)$ & $245.0^{\mathrm{a}}(7.1)$ \\
Dark Blue & $13.1(18.4)$ & $198.0^{\mathrm{c}}(5.0)$ \\
Blue & $16.5(15.3)$ & $212.6^{\mathrm{b}}(4.9)$ \\
Light Blue & $9.5(21.3)$ & $183.5^{\mathrm{c}}(5.3)$ \\
\hline
\end{tabular}

a, b, c - values in the columns with different superscrip differ significantly $(\mathrm{P}<0.05)$

Value in italic parentheses: coefficient of variation $(\mathrm{CV}, \%)$

Table 3. Particle Size of Bukit Kamangs' Limestone

\begin{tabular}{rc}
\hline Particle size $(\mathrm{mm})$ & Percentage $(\%)$ \\
\hline$>4.750$ & 0.0 \\
$4.750-2.000$ & 0.1 \\
$2.000-0.841$ & 5.0 \\
$0.841-0.420$ & 12.7 \\
$0.420-0.250$ & 7.5 \\
$0.250-0.149$ & 12.1 \\
$0.149-0.075$ & 2.1 \\
$<0.075$ & 60.4 \\
\hline Total & 100.0 \\
\hline
\end{tabular}

\section{RESULTS AND DISCUSSIONS}

\section{Hardness of Limestone Composites}

Results of hardness test of composites of Bukit Kamangs' limestone classified according slab colors were shown in Table 2. The most hard composites was found by the black color of 23.4 HRc-C or 245.0 BHN, followed by the composites with the blue, dark blue and light blue colors, respectively. The clear white composite was the most fragile slabs. According to Taggart (1994) the hardness of stones was affected by their mineral composition, like iron, manganese and silver. The stone slabs with colors of black and blue contained high $\mathrm{Fe}$ (Khalil and Anwar, 2007). Brady (1997) reported that calcite with black color contained highly manganese oxide and also a little bit silver.

Moreover, black composite consisted of solid and compacted particle structures. There were a need of much more energy than the other composites to crack and crush into small particles by processing the stone into meal product. These were the main reason why the large particle size found in the meal product were dominated by the black composite. On the other hands, the composites with light blue and clear white colors composed mainly of fragile like-crystal structures, so that their hardness degree was relatively low. In the meal product, most of fine particles were originated from these composites.

In relation to the efficiency of mill performances, the variation in hardness degree of limestone composites of Bukit Kamang brought relatively no consequence. There was no need to separate the composite before milling. According to Taggart (1994) hardness degree of composites of Bukit Kamangs' limestone presented in range of 169-267 BHN which were classified as medium level. It means that the same machine could be used in processing of the stone with different composites to produce meal product. Consequently, the mill machines of Jaw Crusher and Hammer Mill type that recently used by mill industry of CV. Bukit Raya in producing meal product were found suitable to process the Bukit Kamangs' limestone for poultry feed.

\section{Particle Size Distribution}

Table 3 shows data on particle size of Bukit Kamangs' limestone. In general, particle size of Bukit Kamangs' limestone was classified into three groups. The first group was fine particles with the size of $<0.075 \mathrm{~mm}(<4$ mash $)$ and consisted of about $60.4 \%$. Secondly were medium particles $(0.075-0.42 \mathrm{~mm})$ of about $21.7 \%$. The third group was large particle with the size of $>0.24 \mathrm{~mm}$ and consisted of about $17.8 \%$. The meal particle was dominated by fine and medium size which covered about $82.1 \%$. It was a normal particle size in mineral feed in the form of meal. Both particles originated from three relatively fragile composites of dark blue, light blue and clear white colors. These could be recognized from the meal product color which was bluish 
Table 4. Average Moisture Content and Physical Properties of Mineral Feed Stored for 12 Weeks

\begin{tabular}{|c|c|c|c|c|c|}
\hline \multirow{2}{*}{ Parameter } & \multicolumn{5}{|c|}{ Treatments } \\
\hline & $\mathrm{P} 1$ & $\mathrm{P} 2$ & P3 & $\mathrm{P} 4$ & P5 \\
\hline Moisture content, $\%$ & $2.40^{\mathrm{b}}(9.20)$ & $1.30^{\mathrm{d}}(2.00)$ & $0.69^{\mathrm{e}}(12.60)$ & $3.48^{\mathrm{a}}(3.91)$ & $1.70^{\mathrm{c}}(0.10)$ \\
\hline Angle of response, ${ }^{\circ}$ & $56.30^{\mathrm{a}}(1.20)$ & $54.00^{\mathrm{a}}(0.90)$ & $55.46^{\mathrm{a}}(0.45)$ & $52.55^{\mathrm{a}}(0.18)$ & $39.50^{\mathrm{b}}(2.50)$ \\
\hline Bulk density, $\mathrm{kg} / \mathrm{m}^{3}$ & $1379.7^{\mathrm{b}}(0.30)$ & $1478.4^{\mathrm{a}}(0.30)$ & $1475.6^{\mathrm{a}} \quad(0.06)$ & $1253.9^{\mathrm{c}}(0.11)$ & $1486.6^{\mathrm{a}}(0.40)$ \\
\hline $\begin{array}{l}\text { Compacted bulk } \\
\text { density, } \mathrm{kg} / \mathrm{m}^{3}\end{array}$ & $2057.1^{\mathrm{a}}(0.50)$ & $1965.5^{\mathrm{a}}(1.60)$ & $1928.3^{\mathrm{a}} \quad(0.42)$ & $1603.0^{\mathrm{b}} \quad(0.35)$ & $1664.5^{\mathrm{b}}(0.20)$ \\
\hline
\end{tabular}

a. b. c. d. e - values in the rows with different superscrip differ significantly $(\mathrm{P}<0.05)$

Value in italic parentheses: coefficient of variation $(\mathrm{CV}, \%)$

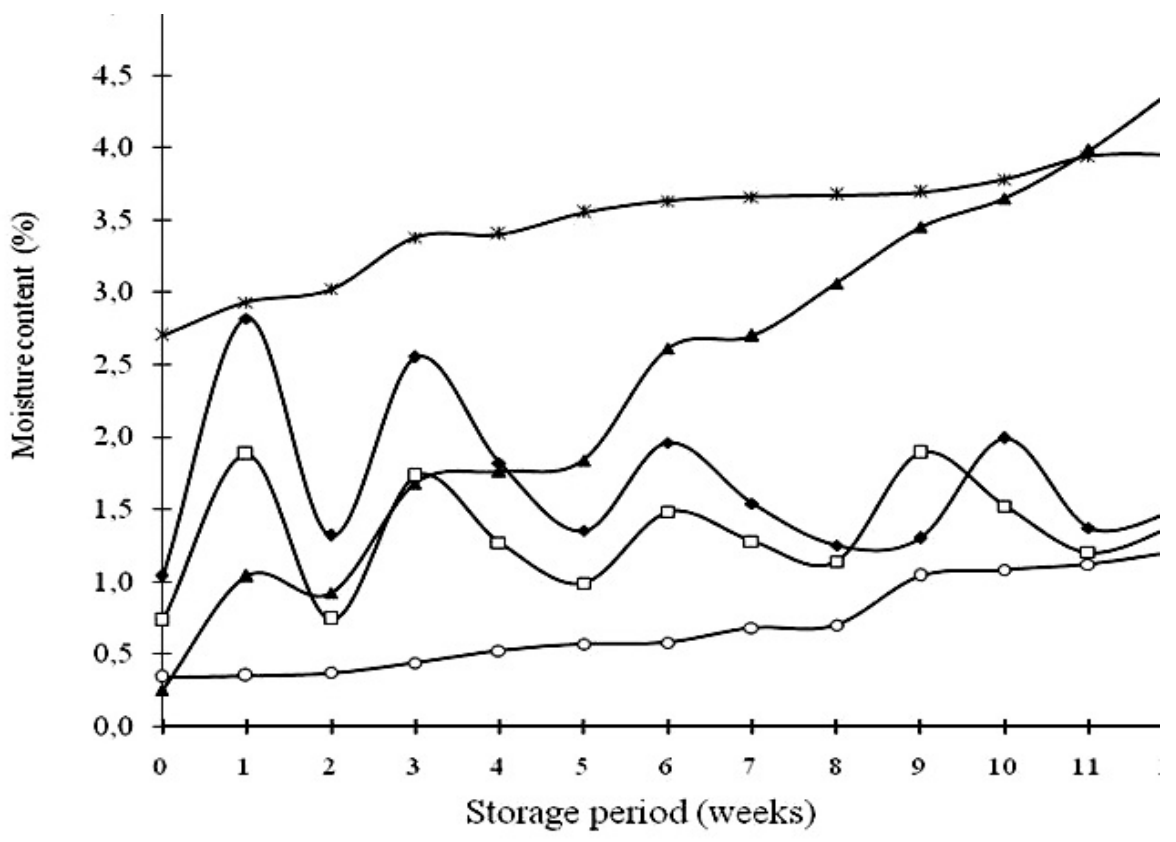

Figure 2. Changes of Moisture Content of Mineral Formulas During Storage for 12 Weeks (. $\mathbf{\Delta}: 100 \%$ Bukit Kamang's limestone (P1); O: 50\% Bukit Kamang's limestone $+50 \%$ freshwater oyster shell meal (P2); $\diamond: 35 \%$ Bukit Kamang's limestone $+30 \%$ freshwater oyster shell meal $+35 \%$ bone meal (P3); X: $35 \%$ Bukit Kamangs' limestone $+30 \%$ fresh water oyster shell meal $+34,2 \%$ bone meal $+0,5 \%$ salt + $0,3 \%$ micro minerals of $\mathrm{Cu}, \mathrm{Zn}$ and I (P4); $: 100 \%$ fresh water oyster shell meal (P5))

white. By milling process, these fragile composites were easily broken, so that they became main component of meal product with fine particles.

Large particle group with the size of over $0.42 \mathrm{~mm}$ embraced about $17.8 \%$. Most of them originated from black composite. From nutritional aspect, the large and hard particles might give positively effect on nutrient metabolism in the digestive tracts. Beside as mineral source, they help nutrient digestion as grit in gizzard which leads to improve feed utilization efficiency. The optimal size of grit for laying hens ranged between 0.5-2.0 mm (Richter et al., 1999), while Witt (2009) mentioned 1.4-5.6 mm. According to Scholtyssek (1987), chicken required 7-9 g grit per month and affectivity of grit in gizzard depended on kind of material and particle size. The more favorable grit originated from resisted material to digestive tract enzymes or acid liquid $(\mathrm{HCl})$, like granite, flint and quartz. The use of coarse ground oyster shell could not give effect as good as grit from stone. Several research reports shown that the use limestone meal with larger particle size in the diets of laying hens increased egg production, eggshell quality and bone 
parameters (Ekmay and Coon, 2010; Safaa et al. 2008; Manangi and Coon, 2006).

\section{Change of Moisture Content and Physical Properties}

The average data on moisture content and physical properties of Bukit Kamangs' limestone and their formula products by storing for 12 weeks are presented in Table 4. The highest moisture content of about $3.48 \%$ was found by complete mineral formula (P4) composed of Bukit Kamangs' limestone. fresh water oyster shell meal. bone meal. salt and micro minerals. followed by the formula of $100 \%$ Bukit Kamangs' limestone (P1) and $100 \%$ fresh oyster shell meal (P5), respectively. The lowest moisture content of $0.69 \%$ was found by the mineral formula consisted of limestone and fresh water oyster shell (P3).

As shown in Figure 2. moisture content of all formulas increased during 12 weeks storage. The highest increase was found by $100 \%$ limestone formula (P1). where the moisture increased consistently from $0.25 \%$ to $4.40 \%$ at the of the storage period. By mixing limestone with fresh water oyster shell meal (P2) and bone meal (P3) could hamper the increase degree of moisture content. so that the moisture content of both formulas ( $\mathrm{P} 2$ and $\mathrm{P} 3$ ) were during storage slightly lower that of mineral formula with $100 \%$ fresh water oyster shell meal (P5). Even though complete mineral formula (P4) showed the highest moisture content at the early storage period. the increase of its moisture during storage was not so high as formula with $100 \%$ limestone (P1). At the end of storage period. the moisture content of P4 was lower that of P1.

As presented at Table 4. physical properties measured were significantly difference with different mineral formulas. Formulas containing Bukit Kamangs' limestone (P1, P2, P3 and P4) showed not significantly difference in angle of responses. The lowest angle of response $\left(39.5^{\circ}\right)$ as found by formulas containing $100 \%$ of fresh water oyster shell meal. Fresh oyster shell meal had higher particle size than limestone and bone meal. so that particles in fresh water oyster shell stacks were more mobile than that of limestone and bone meal (Khalil, 2006). On the other side. mineral formula of $100 \%$ of Bukit Kamangs; limestone (P1) shown the lowest bulk density $\left(1379.7 \mathrm{~kg} / \mathrm{m}^{3}\right)$ and significantly lower than that of all formula containing fresh water oyster shell meal (P2, P3, P4 and P5). When the formulas were compacted, the formula containing $100 \%$ of Bukit Kamangs' limestone (P1) had the highest compacted bulk density value of $2057.1 \mathrm{~kg} / \mathrm{m}^{3}$. There were not significantly changes of all physical properties during the storage. It means that the changes of moisture content gave no significant effect on physical properties measured.

\section{Laying Performance}

Table 5 showed the performances of laying hens fed with diets containing different mineral formulas for 24 weeks. Data on body weight and feed intake were found not significant differences amongst the treatments. but mineral formulas

Table 5. Body Weight. Feed Intake. Feed Conversion Ratio. Mortality and Egg Production of Laying Hens Fed Diets Containing Different Mineral Formula Sources for 24 Weeks

\begin{tabular}{lrrrrrr}
\hline & \multicolumn{7}{c}{ Experimental diets with mineral formula sources: } \\
\cline { 2 - 8 } & \multicolumn{1}{c}{$\mathrm{P} 1$} & \multicolumn{1}{c}{$\mathrm{P} 2$} & \multicolumn{1}{c}{$\mathrm{P} 3$} & $\mathrm{P} 4$ & \multicolumn{1}{c}{$\mathrm{P} 5$} \\
\hline Initial body weight, g/bird & $1505.0(11.1)$ & $1473.3(12.5)$ & $1408.7(10.3)$ & $1411.0(9.9)$ & $1466.0(13.2)$ \\
Final body weight, g/bird & 1659.3 & $(3.8)$ & $1642.0(3.0)$ & $1633.3(7.2)$ & $1604.0(5.3)$ & $1670.3(1.4)$ \\
Total feed intake, g/bird & 20659.2 & $(1.5)$ & $20500.8(0.3)$ & $19738.5(1.0)$ & $19500.2(2.7)$ & $20223.8(0.5)$ \\
Daily feed intake, g/bird & $123.0(1.5)$ & $122.0(0.3)$ & $117.5^{2}(1.0)$ & $116.1(2.7)$ & $120.4(0.5)$ \\
Egg production, eggs/bird & $131.0^{\mathrm{b}}(1.4)$ & $126.2^{\mathrm{c}}(3.9)$ & $126.2^{\mathrm{c}}(8.0)$ & $137.6^{\mathrm{a}}(6.1)$ & $114.7^{\mathrm{d}}(4.8)$ \\
Egg production, g/bird & $7391.3^{\mathrm{b}}(1.4)$ & $7159.0^{\mathrm{c}}(1.2)$ & $7098.8^{\mathrm{c}}(7.1)$ & $7734.6^{\mathrm{a}}(3.1)$ & $6444.9^{\mathrm{d}}(0.4)$ \\
Hen-day egg production, \% & $77.9^{\mathrm{b}}(1.5)$ & $75.1^{\mathrm{c}}(3.9)$ & $75.1^{\mathrm{c}}(7.9)$ & $81.9^{\mathrm{a}}(6.1)$ & $68.3^{\mathrm{d}}(4.8)$ \\
Feed conversion ratio & $2.80^{\mathrm{b}}(0.0)$ & $2.86^{\mathrm{b}}(2.0)$ & $2.78^{\mathrm{b}}(6.2)$ & $2.52^{\mathrm{c}}(4.4)$ & $3.14^{\mathrm{a}}(4.8)$ \\
\hline
\end{tabular}

a. b. c. $\mathrm{d}$ - values in the rows with different superscript differ significantly $(\mathrm{P}<0.05)$

Value in italic parentheses: coefficient of variation (CV. \%) 
gave significant effect on egg production and feed conversion ratios. Laying hens fed diet supplemented with mineral formula containing $100 \%$ of Bukit Kamang's limestone (P1) showed higher egg productions $(\mathrm{P}<0.05)$ in term of number (131 egg/bird). weight (7391 g/bird) and hen-day production $(77.9 \%)$ than that supplemented with mineral formulas containing limestone. fresh water oyster shell and bone meal. (P2, P3 and P5). The highest egg production and the best feed conversion ratio $(\mathrm{P}<0.05)$ were found by laying hens fed with diet supplemented with mineral formula containing limestone. fresh water oyster shell and fortified with micro minerals (P4). The egg production and feed utilization efficiency were significantly improved by fortifying mineral mixture of limestone. Fresh water oyster shell meal and bone meal with micro minerals of $\mathrm{Cu}$. Zn and I (P4). These essential minerals are constituents of hundreds of proteins involved in intermediary metabolism. hormone secretion pathways and immune defense systems (Dieck et al., 2003; Richards et al., 2006). The beneficial effects of $\mathrm{Cu}$. $\mathrm{Zn}$ and I supplementation on laying performances were reported by Swiatkiewicz and Koreleski (2008). El-Husseiny et al. (2009) and Cepuliene et al. (2008).

Mixture of Bukit Kamangs' limestone with fresh water oyster shell (P2 and P3) did not give positive effect on laying performances and feed utilization efficiency. Moreover. the hens fed diet supplemented with mineral formula containing $100 \%$ fresh water oyster shell (P5) showed the poorest egg production and feed conversion ratio $(\mathrm{P}<0.05)$. Previous studies indicated that limestone of Bukit Kamang contained higher calcium (38-40\% Ca) (Khalil and Anwar. 2007) than that of fresh water oyster shell $(26-31 \% \mathrm{Ca})$ (Khalil, 2003). Bukit Kamang's limestone were also rich on micro minerals of $\mathrm{Mn}$. $\mathrm{Fe}$ and $\mathrm{Se}$ (Khalil and Anwar. 2007). These minerals are involved in many digestive. physiological and biosynthetic processes through enzyme system within the body (Abdallah et al., 2009, Berger, 2006).

Moreover. the positive effect of Bukit Kamangs' limestone was due to their beneficial physical properties. particularly with respect to hardness and larger particle size. Results of particle size measurement shown that limestone of Bukit Kamang in meal form consisted of larger particles which were dominated by the hardest composite of black color (Table 2). Richter et al. (1999) found that optimal particle size of limestone for laying hens was $0.5-2.0 \mathrm{~mm}$. while about $18 \%$ of Bukit Kamangs' limestone meal had particle size of 0.5-2.0 mm (Table 3). According to Roland (2000), any particle of calcium sources exceeding about $1 \mathrm{~mm}$ in size will retained in the gizzard and the calcium will be released slowly into the blood stream, while the smaller particles moved quickly through the digestive tract and were only partially dissolved.

\section{CONCLUSIONS}

Based on the results of the study, it was concluded that Limestone of Bukit Kamang consisted of composites in different hardness. The highest hardness degree was found by black composite of about 23.4 HRc-C or 245.0 BHN followed by the blue, dark blue, light blue and clear white. respectively. Meal product consisted of large $(>0.42 \mathrm{~mm})$ of about $17.8 \%$ which mostly originated from black composite. Moisture content of Bukit Kamangs' limestone increased during storage, but there were not significant changes of physical properties. Mixing the limestone with locally available materials of fresh water oyster shell and bone meal could minimize the moisture changes, but there were no significant effects on its nutritive values. Laying performances were on the other hand significantly improved by fortifying Bukit Kamangs' limestone with micro minerals.

\section{REFERENCES}

Abdallah. A.G.. O.M.El-Husseiny and K.O. Abdel-Latief. 2009. Influence of some dietary organic mineral supplementations on broiler performance. Int. J. of Poult. Sci.. 8(3):291-298.

Berger, L. 2006. Salt and Trace Minerals for Livestock. Poultry and Other Animals $\left(8^{\text {th }}\right.$ Ed). Salt Institute. Alexandria. Virginia.

Brady, G. S. 1997. Material Handbook. $14^{\text {th }}$ ed. Book of Mineral Dressing. Ores. Industrial Minerals. McGraw Hill Inc. New York.

Cepuliene, R., R. Bobiniene, V. Sirvydis, D. Gudaviciute, M. Miskiniene and I. Kepaliene, 2008. Effect of stable iodine preparation on the quality of poultry products. Veterinarija Ir Zootechnika, T.42. N.64:38-43.

Dieck,. H.T.. F. Doring, H.P. Roth and H. Daniel. 2003. Changes in rat hepatic gene expression 
in response to zinc deficiency as assessed by DNA array. J. Nutr.. 133:1004-1010.

Ekmay. R.D and C.N. Coon. 2010. The effect of limestone particle size on the performance of three broiler breeder pureline. Int. J. Poult. Sci.. 9(11):1038-1042.

El-Husseiny. O.. S.A. Fayed and L.L. Omara. 2009. Response of layer performance to iron and copper pathway and their interactions. Australian J. Basic and Appl. Science.. 3(3):4199-4213.

Farmer. M.. D.A. Roland Sr and A.J. Clarc. 1986. Influence of dietary calcium on bone calcium utilization. Poult. Sci. (65):337-344

Khalil. 2003. Analisa rendemen dan kandungan mineral cangkang pensi dan siput dari berbagai habitat air tawar di Sumatera Barat. J. Peternakan dan Lingkungan. 09(3): 35-41

Khalil. 2006. Pengaruh penggilingan dan pembakaran terhadap kandungan mineral dan sifat fisik kulit pensi (Corbiculla $s p$ ) untuk pakan. Media Peternakan. 29(2):70-75

Khalil and S. Anwar. 2007. Studi komposisi mineral tepung batu Bukit Kamang sebagai bahan baku pakan sumber mineral. Media Peternakan. 30(1):18-25

Khalil and S.Anwar. 2009. Limestone of Bukit Kamang as a Calcium Source for Laying Hens. Jurnal Pengembangan Peternakan Tropis.34(3): 174-180

Khalil. 2010. Penggunaan Formula Mineral Lokal dalam Ransum Ayam Petelur. Media Peternakan. 33(2):115-123

Khalil. 1999a. Pengaruh kandungan air dan ukuran partikel terhadap sifat fisik pakan lokal: 1. Kerapatan tumpukan. kerapatan pemadatan tumpukan dan berat jenis. Media Peternakan. 22 (1):1-11

Khalil. 1999b. Pengaruh kandungan air dan ukuran partikel terhadap sifat fisik pakan lokal: 1. Sudut tumpukan. daya ambang dan faktor higroskopis. Media Peternakan. 22(1):33-42

Manangi. M. and C.N. Coon. 2006. Calcium particle size effects on plasma. excreta and urinary $\mathrm{Ca}$ and $\mathrm{P}$ changes in broiler breeder hens. Poult. Sci.. 85(Supplement 1):30.

NRC (National Research Council). 1994. Nutrient Requirements of Poultry. National Academic
Press, Washington, DC.

Richards. J. T. Hampton. C. Weulling. M. Wehmeyer and J.J. Dibner. 2006. Mintrex Zn and Mintrex $\mathrm{Cu}$ organic trace minerals improve intestinal strength and immune response to coccidiosis infection and/or vaccination in broiler. Proc. 2006 Int. Poult. Sci. Forum. Atlanta. GA.

Richter. G.. G. Kiessling. W.I. Ochrimenko and H. Luedke. 1999. Einfluss der Partikelgroesse und der Calciumquelle auf die In-vitroLoeslichkeit des Calciums. die Leistungen und die Eischalenqualitaet bei Legehennen. Arch. Gefleugelk.. 5. 208-213

Roland, D.A.. 2000. Nutrition and feeding for optimum egg shell quality. Proceeding World's Poultry Congress 2000. Montreal. Canada.

Ruttloff. C.. 1981. Mischfuttertechnologie. VEB Fachbuchverlag. Leipzig.

Safaa. H.M.. M.P. Serrano. D.F. Valencia. M. Frika. E. Jimenez-Moreno and G.G. Mateo. 2008. Productive performance and egg quality of brown egg-laying hens in the late phase of production as influenced by level and source of calcium in the diet. Poult. Sci.. 87:2043-2051

Scholtyssek, S. 1987. Gefluegel. Eugen Ulmer Verlag.

Steel. R.G.D and J.H. Torrie. 1981. Principles and Procedures of Statistics. McGraw-Hill International Book Company. Aucland.

Swiatkiewicz. S. and J. Koreleski. 2008. The effect of zinc and manganese source in the diet for laying hens on eggshell and bone quality. Veterinarni Medicina. 53(10):555563

Tabor. D.. 2000. The Hardness of Metals. Oxford University Press.

Taggart. A. F. 1994. Handbook of Mineral Dressing. Ores. Industrial Minerals. McGraw Hill Inc. London.

Witt. F.H.. N.P. Kuleite. H.J. Van Der Merwe and M.D. Fair. 2009. Effect of limestone particle size on egg production and eggshell quality of hens during late production. South African J. Anim. Sci.. (29)(Supplement 1):37-40. 